Research Article

\title{
Sleeping Quality Does Not Affect Blood Pressure among Elderly in Tresna Werdha Nursing Home City of Bandung
}

\author{
Vani S Mohani, ${ }^{*}$ Titing Nurhayati**, Dian M Sari**** \\ *Faculty of Medicine Padjadjaran University \\ ** Department of Anatomy, Physiology, and Biology Cell, \\ Faculty of Medicine Padjadjaran University \\ **** Department of Physical Medicine and Rehabilitation \\ Faculty of Medicine Padjadjaran University \\ Jl. Prof. Eyckman No. 38 Bandung 40161 Indonesia \\ Email:vanishafira@gmail.com
}

\begin{abstract}
Bad sleep quality is often associated with rise in blood pressure. However, there are still differences between measurement done in elderly respondents and other age categories. Thus, the aim of this study is to determine association between the quality of sleep with blood pressure among the elderly in Tresna Werdha nursing home city of Bandung. This is an analytical study with cross-sectional design. Respondents in this study are 51 elderly people. Pittsburgh Sleep Quality Index (PSQI) questionnaire is used to measure sleep quality. Blood pressure is categorized into normal blood pressure and hypertension. Data analysis is done by using Chi-square analysis test with a significance value $p<0.05$. The result of this study shows $p=0.113$ for systolic pressure and $p=0.543$ for diastolic pressure. This study concludes that there is no association between sleep quality and blood pressure among the elderly in Tresna Werdha nursing home city of Bandung.
\end{abstract}

Keywords : sleeping quality, elderly, nursing home, blood pressure 


\title{
Kualitas Tidur Tidak Mempengaruhi Tekanan Darah pada Lansia di Panti Sosial Tresna Werdha Kota Bandung
}

\author{
Vani S Mohani", Titing Nurhayati ${ }^{* *}$, Dian M Sari**** \\ *Fakultas Kedokteran Universitas Padjadjaran \\ *** Departemen Ilmu Anatomi, Fisiologi, dan Biologi Sel, \\ Fakultas Kedokteran Universitas Padjadjaran \\ *** Departemen Ilmu Kedokteran Fisik dan Rehabilitasi, \\ Fakultas Kedokteran Universitas Padjadjaran \\ Jl. Prof. Eyckman No. 38 Bandung 40161 Indonesia \\ Email : vanishafira@gmail.com
}

\begin{abstract}
Abstrak
Kualitas tidur yang buruk seringkali dikaitkan dengan peningkatan tekanan darah. Namun, masih terdapat perbedaan hasil antara pengukuran yang dilakukan pada responden lansia dengan kategori umur lainnya. Penelitian ini dilakukan untuk mengetahui hubungan antara kualitas tidur dengan tekanan darah pada lansia di Panti Sosial Tresna Werdha Kota Bandung. Penelitian ini menggunakan metode analitik dengan rancangan potong lintang. Responden dalam penelitian ini berjumlah 51 orang dengan kategori umur lansia. Instrumen yang digunakan adalah kuesioner Pittsburgh Sleep Quality Index (PSQI) untuk menilai kualitas tidur. Tekanan darah dikategorikan menjadi normal dan hipertensi. Data dianalisis menggunakan uji analisis Chi-square dengan nilai signifikasi $\mathrm{p}<0.05$. Dari hasil penelitian didapatkan nilai $\mathrm{p}=0,113$ untuk tekanan sistolik dan $\mathrm{p}=0,543$ untuk tekanan diastolik, sehingga dapat disimpulkan bahwa tidak terdapat hubungan antara kualitas tidur dengan tekanan darah pada lansia di Panti Sosial Tresna Werdha Kota Bandung
\end{abstract}

Kata Kunci: kualitas tidur, lansia, panti sosial, tekanan darah 


\section{Research Article}

\section{Pendahuluan}

Tidur merupakan kondisi penurunan kesadaran yang dapat dibangunkan dengan adanya rangsangan. ${ }^{1}$ Tidur merupakan periode istirahat bagi tubuh dan pikiran yang ditandai dengan penurunan kesadaran secara parsial atau sepenuhnya. ${ }^{2}$ Tidur merupakan kebutuhan dasar manusia yang sangat diperlukan untuk menjaga fungsi tubuh dalam keadaan sehat. Hal ini ditunjukkan pada saat tidur mencapai fase non - rapid eye movement (NREM), gelombang otak mengalami penurunan sehingga menurunkan aktivitas dasar tubuh seperti tekanan darah, detak jantung, laju pernapasan dan lain - lain dalam keadaan basal. ${ }^{2}$

Pada usia dewasa fase periode NREM akan terjadi selama 70 - 100 menit dan akan diikuti oleh periode tidur REM. Siklus ini akan berulang tiap 90 menit dalam satu malam. Berbeda dengan usia dewasa dan anak-anak, pada lansia fase NREM tingkat 3 dan 4 akan menjadi lebih pendek, hal ini menyebabkan lansia lebih sering untuk terbangun di malam hari. ${ }^{3,4}$

Kebutuhan terbesar yang dibutuhkan pada masa lansia adalah tingkatan kesehatan agar dapat hidup sejahtera. ${ }^{5}$ Namun, seiring bertambahnya usia akan terjadi penuruanan kualitas tidur pada lansia dan hal ini dapat mempengaruhi kesehatan. ${ }^{6,7}$ Hasil penelitian sebelumnya menghipotesiskan bahwa tidur yang kurang dari tujuh jam dapat meningkatkan risiko penyakit kardiovaskular ditandai dengan peningkatan tekanan darah. ${ }^{8}$ Penelitian yang dilakukan oleh James E. Gangwisch dkk tahun 2006 menunjukkan bahwa durasi tidur yang $\leq 5$ jam dapat meningkatkan risiko hipertensi secara signifikan. ${ }^{9}$ Hasil studi yang dilakukan oleh Maple M. Fung dkk tahun 2011 menunjukkan penurunan durasi slow wave sleep pada lansia dapat meningkatkan risiko hipertensi. ${ }^{10}$ Hasil penelitian yang dilakukan oleh Hye-Rim Hwang dkk didapati bahwa seseorang yang tidur dengan durasi kurang dari lima jam dapat mengalami peningkatan untuk dberikan pengobatan hipertensi dibandingkan yang tidur selama tujuh jam atau lebih. ${ }^{11}$

Hal di atas bertolak belakang dengan penelitian yang dilakukan oleh Yue Ji-Rong dkk. Hasil penelitian tersebut menjelaskan bahwa tidak ditemukannya hubungan antara kualitas tidur dan tekanan darah pada orang lansia. ${ }^{12}$ Variasi hasil penelitian-penelitian sebelumnya membuat kualitas tidur sebagai salah satu faktor risiko yang dapat memengaruhi tekanan darah perlu diteliti pada lansia di Panti Sosial Tresna Werdha Kota Bandung.

\section{Metode}

Penelitian ini menggunakan metode analitik dengan rancangan potong lintang untuk mengetahui hubungan antara kualitas tidur dengan tekanan darah pada lansia di Panti Sosial Tresna Werdha kota Bandung. Subjek penelitian ini dipilih secara simple random sampling dan penentuan jumlah sampel dalam penelitian ini menggunakan rumus analitik sebesar 51 orang. 


\section{Research Article}

Pengambilan data dilakukan pada bulan Juli-September 2017. Kriteria inklusi pada penelitian ini yaitu, responden berusia $\geq 65$ tahun, tinggal di Panti Sosial Tresna Werdha kota Bandung, dan bersedia menjadi responden pada penelitian ini. Kriteria eksklusi pada penelitian ini adalah responden memiliki riwayat penyakit kardiovaskuler. Variabel yang dinilai dalam penelitan ini adalah kualitas tidur sebagai variabel bebas dan tekanan darah sebagai variabel terikat.

Penelitian ini telah mendapatkan persetujuan etik dari Komite Etik Penelitian Kesehatan Fakultas Kedokteran Universitas Padjadjaran dengan nomor surat 96/UN6.C.10/PN/2017. Data yang digunakan pada penelitian ini adalah data primer yang didapatkan dengan cara melakukan wawancara terhadap subjek menggunakan kuesioner dan melakukan pengukuran tekanan darah pada lansia di Panti Sosial Tresna Werdha kota Bandung.

Kuesioner Pittsburgh Sleep Quality Index (PSQI) digunakan untuk menilai kualitas tidur responden. Parameter yang digunakan pada kuesioner ini adalah dengan menghitung tujuh aspek penilaian, yaitu kualitas tidur secara subjektif, latensi tidur, durasi tidur, efesiensi kebiasaan tidur, gangguan tidur, dan penggunaan obat tidur serta disfungsi tidur pada siang hari selama satu bulan. Kualitas tidur yang baik memiliki jumlah skor $<5$ dan yang buruk memiliki jumlah skor $\geq 5$ dengan skor minimal 0 poin dan maksimal 21 poin. ${ }^{13}$

Tekanan darah diukur menggunakan stetoskop dan sphygmomanometer raksa. Untuk hasil tekanan darah dibedakan menjadi tekanan darah sistolik dan diastolik. Tekanan darah sistolik dengan hasil $<120 \mathrm{mmHg}$ dan $<80 \mathrm{mmHg}$ akan dikategorikan sebagai tekanan darah normal, sedangkan untuk hipertensi dikategorikan dengan tekanan darah sistolik setinggi $\geq 140$ mmHg dan diastolik $\geq 90 \mathrm{mmHg} .{ }^{14}$

Data yang didapat akan dianalisis menggunakan program SPSS dan dilakukan uji Chisquare untuk menentukan hubungan kualitas tidur dengan tekanan darah. Signifikasi uji ditentukan berdasarkan nilai $\mathrm{p}<0,05$. Hasil analisis akan disajikan dalam bentuk tabel.

\section{Hasil}

Penelitian ini dilakukan untuk mengetahui hubungan kualitas tidur terhadap tekanan darah pada lansia yang disajikan dalam data pada tabel berikut. 
Tabel 1 Karakteristik Subjek Penelitian

\begin{tabular}{llll}
\hline No & Karakteristik & Jumlah & Persentase (\%) \\
\hline 1 & Jenis Kelamin & 19 & 37,3 \\
& Laki-laki & 32 & 62,7 \\
\multirow{2}{*}{2} & Perempuan & 32 & 62,7 \\
& Usia & 15 & 29,4 \\
& Lanjut Usia & 4 & 7,9 \\
& Lanjut Usia Tua & & \\
& Usia Sangat Tua & 17 & 33,3 \\
& Kualitas Tidur & 34 & 66,7 \\
& Baik & & \\
4 & Buruk & & 49,0 \\
& Tekanan Darah & 25 & 51,0 \\
& Sistolik & 26 & 41,2 \\
& Normal & & 58,8 \\
& Hipertensi & 21 &
\end{tabular}

Tabel 1 menunjukkan karakteristik subjek penelitian yang didominasi oleh kategori lanjut usia dan jenis kelamin perempuan. Dari hasil pengukuran tekanan darah sistolik dan diastolik didapatkan bahwa responden dengan kondisi hipertensi lebih banyak daripada responden dengan tekanan darah normal sedangkan untuk kualitas tidur didominasi oleh lansia yang memiliki kualitas tidur yang buruk.

Tabel 2 Hubungan Kualitas Tidur dengan Tekanan Darah Sistolik

\begin{tabular}{llllll}
\hline \multicolumn{1}{c}{ Kualitas Tidur } & \multicolumn{4}{c}{ Tekanan Darah Sistolik } & p-value \\
& Normal & \multicolumn{4}{c}{ Hipertensi } \\
& $\mathrm{N}$ & $\%$ & $\mathrm{~N}$ & $\%$ & \\
\hline Baik $(\mathrm{n}=17)$ & 11 & 64,7 & 6 & 35,3 & 0,113 \\
Buruk $(\mathrm{n}=34)$ & 14 & 41,2 & 20 & 58,8 & \\
\hline
\end{tabular}

Tabel 2 menunjukan hubungan kualitas tidur dengan tekanan darah sistolik. Tabel tersebut menunjukkan tidak adanya hubungan antara tekanan darah sistolik dengan kualitas tidur berdasarkan nilai $\mathrm{p}=0,113(\mathrm{p}<0,05)$.

Tabel 3 Hubungan Kualitas Tidur dengan Tekanan Darah Diastolik

\begin{tabular}{llllll}
\hline \multicolumn{1}{c}{ Kualitas Tidur } & \multicolumn{4}{c}{ Tekanan Darah Sistolik } & p-value \\
\hline & Normal & \multicolumn{2}{c}{ Hipertensi } \\
& $\mathrm{N}$ & $\%$ & $\mathrm{~N}$ & $\%$ & \\
\hline Baik $(\mathrm{n}=17)$ & 8 & 47,1 & 9 & 52,9 & 0,543 \\
Buruk $(\mathrm{n}=34)$ & 13 & 38,2 & 21 & 61,8 & \\
\hline
\end{tabular}




\section{Research Article}

Tabel 3 menunjukan hubungan kualitas tidur dengan tekanan darah diastolik. Tabel tersebut menunjukkan tidak adanya hubungan antara tekanan darah sistolik dengan kualitas tidur berdasarkan nilai $\mathrm{p}=0,543(\mathrm{p}<0,05)$.

\section{Diskusi}

Responden yang berpartisipasi pada penelitian ini didominasi oleh responden kategori lanjut usia dan perempuan masing-masing sebanyak 32 responden $(62,7 \%)$, hal ini disebabkan terdapat satu panti yang khusus untuk perempuan sehingga subjek laki-laki menjadi lebih sedikit.

Berdasarkan tabel 1 responden yang mengalami hipertensi sebanyak 26 responden (51\%) untuk kategori sistolik dan 30 responden $(58,8 \%)$ untuk kategori diastolik. Jumlah ini lebih banyak dibandingkan dengan jumlah subjek dengan tekanan darah normal di masing-masing kategori. Hal ini dikarenakan pada lansia telah terjadi proses penuaan yang menyebabkan terjadinya penurunan elastisitasitas pembuluh darah. Perubahan ini dapat menurunkan fungsi dari pembuluh darah arteri sehingga dapat meningkatkan resistensi pada vaskularisasi perifer dan meningkatkan tekanan darah sistolik dan diastolik. ${ }^{12}$

Hasil yang didapatkan untuk pengukuran kualitas tidur pada subjek didominasi memiliki kualitas tidur yang buruk sebanyak 34 responden $(66,7 \%)$. Proses penuaan pada lansia menyebabkan perubahan pada ritme sirkadian yang dapat mempengaruhi siklus bangun dan tidur. Perubahan ini dapat menyebabkan lansia mengalami bangun malam yang lebih sering dibandingkan dengan orang usia dewasa dan remaja sehingga dapat memperpendek durasi tidur. $^{1,6,12}$

Tabel 2 dan 3 menunjukkan tidak ditemukan adanya hubungan antara kualitas tidur dengan tekanan darah sistolik dan diastolik pada lansia. Beberapa jurnal yang menyebutkan bahwa terdapat hubungan yang signifikan dari kualitas tidur yang buruk dengan prevalensi peningkatan tekanan darah rata-rata mengambil subjek pada usia $<65$ tahun, sedangkan pada lansia dengan usia $\geq 65$ tahun seperti pada beberapa penelitian tidak ditemukan adanya hubungan antara kualitas tidur dengan tekanan darah. ${ }^{9,10,11}$

Aktivasi saraf simpatis memiliki peran penting yang menghubungkan gangguan tidur dengan peningkatan tekanan darah. Namun pada lansia, peningkatan tekanan darah disebabkan oleh proses penuaan yang menyebabkan degradasi dinding arteri dan ketidaksensitifan terhadap hormon-hormon yang berperan dalam mengatur aktivitas saraf simpatis. ${ }^{12,17}$

Penelitian yang dilakukan oleh Julia F. van den Berg dkk menyebutkan bahwa peningkatan tekanan darah yang dipengaruhi oleh kualitas tidur yang buruk terjadi ketika adanya pembatasan durasi tidur yang disebabkan oleh faktor eksternal, seperti waktu bangun 


\section{Research Article}

yang pasti untuk pergi berkerja. Sedangkan pada lansia yang durasi tidurnya lebih singkat dapat disebabkan oleh proses penuaan yang menyebabkan penurunan kebutuhan tidur. ${ }^{15}$

Beberapa jurnal menyebutkan bahwa kondisi ini juga dapat dipengaruhi oleh kondisi lansia yang rata-rata sudah pensiun memiliki waktu untuk istirahat di siang hari, sehingga dapat menggantikan kebutuhan tidur yang kurang pada malam hari. ${ }^{12,15,17}$ Kondisi ini sesuai dengan penelitian ini dikarenakan semua responden berada di panti sosial sehingga responden pada penelitian ini tidak bekerja lagi dan kegiatan-kegiatan responden dibatasi oleh pihak panti agar tidak terlalu melelahkan responden.

Keterbatasan penelitian ini adalah banyaknya penyakit-penyakit selain penyakit sistem kardiovaskular yang terjadi pada lansia yang dapat menyebabkan munculnya faktor perancu yang dapat mempengaruhi hasil penelitian. Hal ini diharapkan dapat menjadi hal yang diperhatikan pada penelitian-penelitian selanjutnya.

\section{Simpulan}

Pada penelitian ini dapat disimpulkan bahwa tidak ditemukan adanya hubungan antara kualitas tidur dengan tekanan darah sistolik dan diastolik pada lansia.

\section{Daftar Pustaka}

1. C. Guyton A, E. Hall J. Textbook of Medical Physiology. 12th ed. Philadelphia: Elsevier; 2011.

2. M. Anderson D. Dorland's Illustrated Medial Dictionary. In: 32nd ed. USA: Elsevier; 2012.

3. Barrett K, Brooks H, Boitano S, Barman S. Ganong's Review of Medical Physiology. 23rd ed. USA: Lange; 2010.

4. Lauralee S. Human physiology: From cells to system. 7th ed. California: Brooks/Cole; 2010.

5. Stanley M, Gauntlett Beare P. Buku Ajar Keperawatan Gerontik. 2nd ed. Jakarta: EGC; 2007. 502 p.

6. National Sleep Foundation. Aging and Sleep [Internet]. [cited 2017 Jan 12]. Available from: https://sleepfoundation.org/sleep-topics/aging-and-sleep

7. National Institute of Health. Sleep and Aging [Internet]. [cited 2017 Jan 16]. Available from: https://nihseniorhealth.gov/sleepandaging/aboutsleep/01.html

8. Buxton OM, Marcelli E. Social Science \& Medicine Short and long sleep are positively associated with obesity, diabetes, hypertension, and cardiovascular disease among adults in the United States. Soc Sci Med. 2010;71(5):1027-36.

9. Gangwisch JE, Heymsfield SB, Boden-albala B, Buijs RM, Kreier F, Pickering TG, et al. Short Sleep Duration as a Risk Factor for Hypertension Analyses of the First National Health and Nutrition Examination Survey. Hypertension. 2006;47:833-9.

10. Fung MM, Peters K, Redline S, Ziegler MG, Ancoli-Israel S, Barrett-Connor E, et al. Decreased slow wave sleep increases risk of developing hypertension in elderly men. Hypertension. 2011;58(4):596-603.

11. Hwang H, Lee J, Lee S, Cha KS, Choi JH, Jeong D, et al. The relationship between hypertension and sleep duration: an analysis of the fifth Korea National Health and Nutrition Examination Survey ( KNHANES V-3 ). Clin Hypertens. 2015;21:8.

12. Ji-rong Y, Hui W, Chang-quan H, Bi-rong D. Association between sleep quality and arterial blood pressure among Chinese nonagenarians / centenarians. Med Sci Monit. 2012;18(3):36-42.

13. Carole Smyth. The Pittsburgh Sleep Quality Index ( PSQI ). Hartford Inst Geriatr Nurs. 2012;29(6):1-2.

14. C. Kovell L, M. Ahmed H, Misa S, P. Whelton S. US Hypertension Management Guidelines: A Review of the Recent Past and Recommendations for the Future. J Am Heart Assoc. 2015;4.

15. Berg JF Van Den, Tulen JHM, Neven AK, Hofman A, Miedema HME, Witteman JCM, et al. Sleep Duration and Hypertension Sleep Duration and Hypertension Are Not Associated in the Elderly. Hypertension. 2007;50:585-9.

16. Wang D, Zhou Y, Guo Y, Zhang R, Li W, He M, et al. The effect of sleep duration and sleep quality on 


\section{Research Article}

hypertension in middle-aged and older Chinese: the Dongfeng-Tongji Cohort Study. Sleep Med. 2017;40:78-83.

17. Guo J, Fei Y, Li J, Zhang L, Luo Q, Chen G. Gender- and age-speci fi c associations between sleep duration and prevalent hypertension in middle-aged and elderly Chinese : a cross-sectional study from CHARLS $2011-2012$. BMJ Open. 2016;6(9):e011770. 